\title{
Desain Komunikasi Visual Social Media Sebagai Penunjang Informasi dan Promosi Pada PT. Diamas Star
}

\author{
M. Puad Abdul Baqi**1, Sudaksa Hasbi Majid ${ }^{2}$, Yuly Silvia Agustina ${ }^{3}$ \\ Program Studi Teknik Informatika Fakultas Sains dan Teknologi Universitas Raharja \\ E-mail: *11 puad@ raharja.info, ${ }^{2}$ sudaksa.hasbi@ raharja.info, ${ }^{3}$ yuly@ raharja.info
}

\begin{abstract}
Abstrak
PT. Diamas Star adalah sebuah perusahaan yang bergerak di bidang produksi glassware, yang menghasilkan berbagai produk berbahan dasar kaca / glass dari mulai produk yang di hasilkan yaitu lampu, akuarium, vas bunga, stoples, dan gelas, PT. Diamas Star mempunyai banyak persaingan di Kota Tangerang dan juga di tingkat nasional, dengan mengedepankan kualitas dari barang yang dihasilkan dan dalam mencapai sumber daya manusia (SDM) yang berkualitas, memiliki moralitas dan intelektualitas. Dengan kemajuan teknologi sekarang yang sangat pesat di bidang media informasi khususnya di sosial media PT. Diamas Star memanfaatkan media sosial sebagai media promosi dan informasi terhadap produk-produk yang di hasilkannya. Tujuan dibuatnya Desain Komunikasi Visual Social Media Sebagai Penunjang Informasi dan Promosi adalah meningkatkan citra perusahaan dan menaikan penjualan marketing di setiap tahunnya, manfaat dari desain komuniasi visual berbasis digital yaitu social media adalah meingkatkan brand awareness dari produk PT. Diamas Star terhadap konsumen-konsumenya. Hasil dari penelitian akan diupload di social media Mulai dari Instagram, Facebook, dan Youtube untuk menjangkau calon konsumen dari semua kalangan. Dengan demikian perlu di buatkannya desain yang menarik dan informatif untuk menarik perhatian dari calon konsumen dan meningkatkan citra/image PT. Diamas Star di sosial media.
\end{abstract}

Kata Kunci: Sosial Media, Desain Promo, Media Komunikasi Visual

\begin{abstract}
PT. Diamas Star is a company engaged in the production of glassware, which produces a variety of glass-based products, from products that are manufactured, namely lamps, aquariums, flower vases, jars and glasses, PT. Diamas Star has a lot of competition in Tangerang City and also at the national level, by prioritizing the quality of the goods produced and in achieving quality human resources $(H R)$ who have morality and intellectuality. With the current rapid technological advances in the field of information media, especially in social media, PT. Diamas Star uses social media as a media for promotion and information on the products it produces. The purpose of making Visual Social Media Communication Design to Support Information and Promotion is to improve the company's image and increase marketing sales every year, the benefits of digital-based visual communication design, namely social media, are to increase brand awareness of PT. Diamas Star to its customers. The results of the research will be uploaded on social media starting from Instagram, Facebook, and Youtube to reach potential consumers from all walks of life. Thus it is necessary to make an attractive and informative design to attract the attention of potential customers and improve the image / image of PT. Diamas Star on social media.
\end{abstract}

Keywords: Information, Design, Visual Communication

33 


\section{PENDAHULUAN}

PT. Diamas Star adalah produsen utama berbahan dasar glass, Didirikan oleh William Wu pada tahun 1994 PT. Diamas Star, mempunyai beberapa brand dengan berbagai macam produk yang di hasilkan nya, berbasis di Indonesia dan telah memperoleh pasar global dengan standard eropa di industri gelas kaca. PT. Diamas Star mempunyai lebih dari 600 karyawan, diamas telah hadir di Indonesia dan pasar internasional seperti Argentina, Afrika Selatan, Arab Saudi, Australia, Bangladesh, Brazil, Dubai, Republik Ceko, Filipina, India, Jepang, Malaysia, Polandia, Singapura, Thailand, Uruguay, Vietnam, dan Yaman. Kami yakin bahwa material dan teknologi yang kami gunakan akan mendapatkan kepercayaan dan kesetiaan dari pasar.PT. Diamas Star bertujuan menjadi perusahaan yang terbaik dalamdesign, kualitas, dan pelayananya terhadap konsumen. Kami membawa nilai inti kami dan rasa hormat yang kami miliki terhadap orang-orang dan produk kami.Produk kami dibuat oleh seniman gelas berpengalaman yang didukung oleh teknologi pembuatan gelas yang moderen. Setiap produk kami dibuat oleh tangan-tangan terampil dengan teknik tinggi dan proses pengerjaan bertahap agar produk kami menjadi produk yang unik, mudah dikenal, modern dan mudah digunakan.

Promosi melalui media sosial adalah proses pemasaran yang dilakukan melalui pihak ketiga yaitu aplikasi / situs web yang berbasis media sosial. Media sosial yang sering digunakan untuk pemasaran atau promosi antara lain Facebook, Instagram dan Twitter. Melalui media semacam ini, perusahaan atau brand dapat melakukan promosi yang tepat sasaran. Saat ini media sosial sudah banyak tersedia untuk pemasaran atau promosi sebuah produk atau jasa yang di tawarkan oleh suatu perusahaan. ${ }^{[1]}$

Tujuan promosi merupakan kegiatan dari seorang penjual yang berupaya menarik calon konsumen untuk membeli produk atau jasa melalui media seperti brosur, katalog, dan flyer. Promosi juga biasa disebut sebagai pertukaran antara pembeli dan penjual. Melalui promosi ini dapat membantu konsumen lebih mengenal produk yang dijual oleh perusahaan. Dengan adanya promosi dapat membantu meningkatkan brand awareness terhadap produk yang dihasilkan perusahaan dan meningkatkan citra publik perusahaan.Dengan adanya promosi semacam ini juga dapat membangkitkan minat pelanggan potensial dan menarik pelanggan setia. ${ }^{[2]}$

Seiring Perkembangan zaman media sosial semakin banyak dan luas, PT. Diamas Star membutuhkan suatu media visual yang di gunakan untuk sarana promosi dan informasi kepada calon pembeli melalu media sosial dapan menjangkau konsumen di semua kalangan. Melalui desain visualisasi yang menarik diharapkan dapat menarik minat dari calon konsumen dan juga meningkatkan citra perusahan diruang publik. Adapun desain media visual yang di gunakan oleh PT. Diamas Star di sosial media adalah desain InstagramFeed, Instagram Story dalam menyampaikan infromasi dan promosi dari produkyang di tawarkannya.

\section{METODE PENELITIAN}

Dalam penelitian diperlukan beberapa metode penelitian, berikut ada beberaapa metode penelitian yang digunakan oleh penulis dalam penyusunan penulisan diantaranya adalah :

\subsection{Metode Pengumpulan Data}

a. Metode Observasi

Observasi adalah proses mengamati secara cermat dan langsung di lokasi penelitian untuk mendapatkan data-data yang diperlukan dalam penulisan serta melaukan magang pada PT. Diamas Star dibagian desain grafis untuk keperluan sosial media.

a. Wawancara (Interview)

Wawancara dilakukan secara langsung dengan Stakeholder William WUselaku direktur PT. Diamas Star untuk mendapatkan informasi terkait dengan penulisan yang dilakukan. 
c. Studi Pustaka

Sesudah melaksanakan observasi dan wawancara secara langsung penulis jugamengumpulkan data-data yang relevan dengan judul penelitian mulai dari jurnal, artikel, buku-buku, proceeddings dan referensi yang berkaitan dengan pembahasan penulisan.

\subsection{Metode Analisa}

Desain Komunikasi Visual Social Media Sebagai Penunjang Informasi dan Promosi Pada PT. Diamas Star menggunakan 2 software penunjang desain yaitu Corel Draw X7 Adobe Photoshop CC 2014.

\subsection{Literature Review}

Berikut adalah beberapa Literature Review yang di gunakan oleh penulis :

1. Studi yang sudah dilakukan oleh Saputra (2011) dari Universitas Negeri Malang dengan judul "Perancangan Media Komunikasi Visual sebagai Media Promosi Jurusan Multimedia Sekolah Menengah Kejuruan Nasional Malang". Hasil penelitian menjelaskan bahwa perancangan media promosi semacam ini bertujuan untuk membangun image bagi jurusan multimedia, sehingga dapat memberikan informasi dan pertukaran informasi bagi jurusan multimedia di SMK.. ${ }^{[3]}$

2. Riset yang sudah dilakukan oleh Putra (2011) dari Institut Seni Indonesia Denpasar yang berjudul "Perancangan Media Komunikasi Visual sebagai Sarana Promosi SD Saraswati 2 Denpasar". Penelitian ini menjelaskan kurangnya media komunikasi visual SD Saraswati 2 Denpasar untuk media promosi. ${ }^{[4]}$

3. Studi yang suda dilakukan oleh Amirudin (2015) dari Universitas Dian Nuswantoro Semarang yang berjudul "Perancangan Media Komunikasi Visual sebagai Sarana Promosi Perumahan Villa Esperanza di Semarang". Hasil penelitian menunjukkan bahwa perusahaan masih minimnya peluang promosi sehingga menyebabkan masyarakat Kota Semarang dan sekitarnya menyadari hal tersebut. ${ }^{[5]}$

4. Penelitian yang dilakukan oleh Cahyono (2016) dari Universitas Tulungagung yang berjudul "Pegaruh Media Sosial Terhadap Perubahan Sosial Masyarakat di Indonesia". Studi ini menjelaskan bahwa perkembangan teknologi informasi membawa sebuah perubahan dalam masyarakat. Lahirnya media sosial menjadikan pola perilaku masyarakat mengalami pergeseran baik budaya, etikan dan norma yang ada. ${ }^{[6]}$

5. Penelitian yang dilakukan oleh Atik (2016) dari Universitas Negeri Yogyakarta yang berjudul "Unsur Desain Pada Merchandise "Tempa" di Yogyakarta. Design Elements On

"Tempa" Merchandise in Yogyakarta". Penelitian ini bertujuan untuk mendeskripsikan jenis ilustrasi, karakteristik unsur ilustrasi, karakteristik tema pada desain merchandise "Tempa". Penelitian ini merupakan penelitian deskriptif kualitatif. ${ }^{[7]}$

6. Penelitian yang dilakukan oleh Semuel dan Setiawan (2018) dari Universiras Kristen Petra Surabaya "Promosi Melalui Sosial Media, Brand Awareness, Purchase Intentio Pada Produk Sepatu Olahraga". Penelitian ini menganalisa pengaruh promosi, brand awareness, dan purchase intention produk sepatu olahraga di Surabaya melalui sosial media. Sosial media yang digunakan berpromosi berupa foto produk ataupun potongan harga dipublikasikan di Instagram, facebook, dan twitter. ${ }^{[8]}$

7. Penelitian yang dilakukan oleh I M Dedy Setiawan, N P Sukanteri, I M Suryana, dan P K Suparyana (2019) dari Universitas Pendidikan Ganesha, Bali, yang berjudul "Pengaruh 
Promosi Berbasis Sosial Media Terhadap Penjualan Produksi Kelompok Wanita Tani (KWT) Ayu Tangkas di Desa Megati". Tujuan dari penelitian ini adalah untuk mengetahui bagaimana pengaruh promosi berbasis sosial media terhadap hasil penjualan produksi pertanian Kelompok Wanita Tani (KWT) Ayu Tangkas di Desa Megati Kabupaten Tabanan. Penelitian ini dilaksanakan di Desa Megati Kecamatan Selemadeg Barat Kabupaten Tabanan yang melibatkan KWT Ayu Tangkas yang berperan dalam mengolah hasil pertanian menjadi makanan yang siap jual. Penentuan responden ditunjuk secara purposive random sampling. ${ }^{[9]}$

8. Penelitian yang dilakukan oleh Ade Raisha Nurgayatri dan Ama Suyanto (2016) dari Telkom University yang berjudul "Pengaruh Promosi Online Pada Media Sosial Terhadap Keputusan Pembelian Konsumen Brand Elmeira". Penelitian ini bertujuan untuk mengetahui pengaruh promosi online pada media sosial terhadap keputusan pembelian konsumen brand Elmeira. Variabel independen yang diteliti yaitu: Personal relevance (X1), Interactivity (X2), Message (X3), Brand familiarity (X4) dengan variabel dependen yaitu keputusan pembelian pada konsumen Elmeira menggunakan model respon AIDA (attention, intersert, disire, action). ${ }^{[10]}$

9. Penelitian yang dilakukan oleh Ratna Dumilah, Ading Sunarto, Ahyani Ahyani, Dede Solihin, dan Hira Maulida (2020) dari Universitas Pamulang yang berjudul "Pelatihan Pemanfaatan Media Sosial Untuk Promosi Usaha Atau Bisnis Bagi Siswa”. Penelitian ini bertujuan untuk kegiatan pengabdian masyarakat ini adalah untuk meningkatkan kemampuan berpikir siswa atau warga belajar PKBM Negeri 26 Bintaro dalam memanfaatkan media sosial untuk promosi bisnis. ${ }^{[1]}$

10. Penelitian yang dilakukan oleh Deru R Indika dan Cindy Jovita (2017) dari Universitas Padjadjaran, Bandung yang berjudul "Media Sosial Instagram Sebagai Sarana Promosi Untuk Meningkatkan Minat Beli Konsumen". Penelitian ini bertujuan untuk memudahkan orang mendapatkan informasi di bidang pemasaran, hal ini mempengaruhi bagaimana promosi dilakukan oleh antar individu melalui media sosial instagram.

\section{HASIL DAN PEMBAHASAN}

\subsection{Konsep Perancangan}

Dalam konsep perancangan media Komunikasi Visual Social Media Sebagai Penunjang Media Informasi dan Promosi Pada PT. Diamas Star ini memiliki beberapa konsep perancangan yang dilakukan yaitu diantaranya sebagai berikut :

\section{Perencanaan Media}

Desain komunikasi visual yang digunakan sebagai media informasi dan promosi pada Social Media PT. Diamas Star adalah Desain-desain yang dirancang dengan menarik dan informatif sesuai kebutuhannyadengan ukuran 1:1 dan 6:19. Semua konten yang dapat menunjang media informasi, promosi serta brand awareness pada PT. Diamas Star dalam menarik konsumen baru dan menjaga konsumen tetap.

\section{Perencanaan Pesan (Konsep Kreatif)}

Konsep yang digunakan pada desainsocial mediaberkesan modern dan simple yaitu dengan gaya desain yang menarik dan informatif serta menggunakan warna-warna cerah, dan juga penggunaan font yang sesuai dengan tema desain yang dibuat sesuai kebutuhan PT. Diamas Star.

3. Pengarahan Visual

Penyampaian desain social media khususnya didesain Feed dan Story Instagram Menggunakan warna cerah dan digabungkan dengan pemilihan font yang sesuai seperti 
font. Futura, Futura BK Bold, Futura BK Italic, Century Gothic.

3.2 Tujuan dan manfaat Desain Komunikasi Visual Social Media Sebagai Penunjang Informasi dan Promosi Pada PT. Diamas Star

Tujuan dan manfaat dibuatnya desain social media adalah untuk menyampaikan informasi dari produk yang dihasilkan oleh perusahaan kepada para calon konsumen serta menaikkan penjulan dan meningkatkan laba/keuntungan.Promosi juga ditujukan untuk mendapatkan pelanggan baru dan mempertahankan loyalitas pelanggan lama.Dengan bantuan media promosi dapat meningkatkan branding dan membentuk citra produk perusahaan dimata konsumen.

\subsection{Layout Kasar}

Layout kasar adalah sebuah gambaran kerja yang masih berbentuk sebuah sketsa.Layout kasar ini dibuat dibuat secara manual dengan hitam putih menggunakan coretan pensil dan menjadi referensi gambar saat tahap komputerisasi.
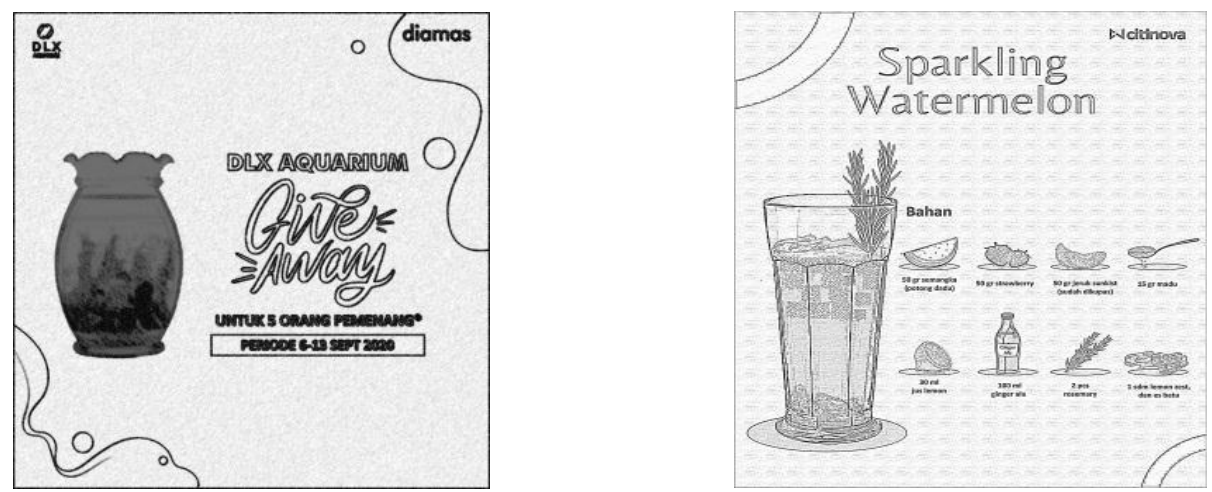

Gambar 1 dan 2. Tampilan Layout kasar dari desain Give Away Feed Instagram DLX Aquarium dan Desain infografis menu Sparkling Watermelon Instagram Feed Citinova.
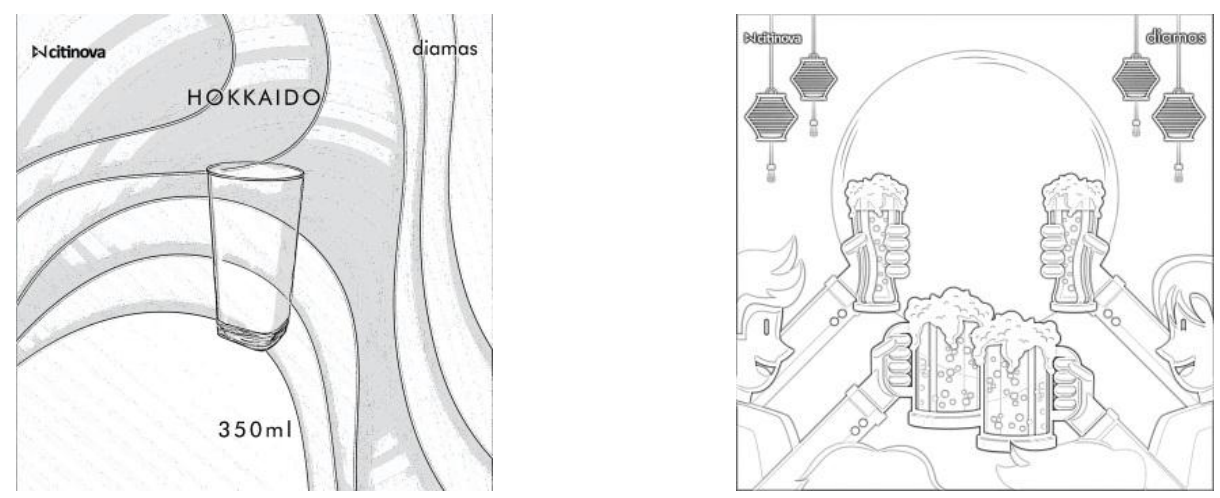

Gambar 3 dan 4. Tampilan Layout kasar dari Desain produk Feed Instagram Citinova dan Desain Feed Instagram Ucapan Selamat Hari Raya Imlek 2021. 

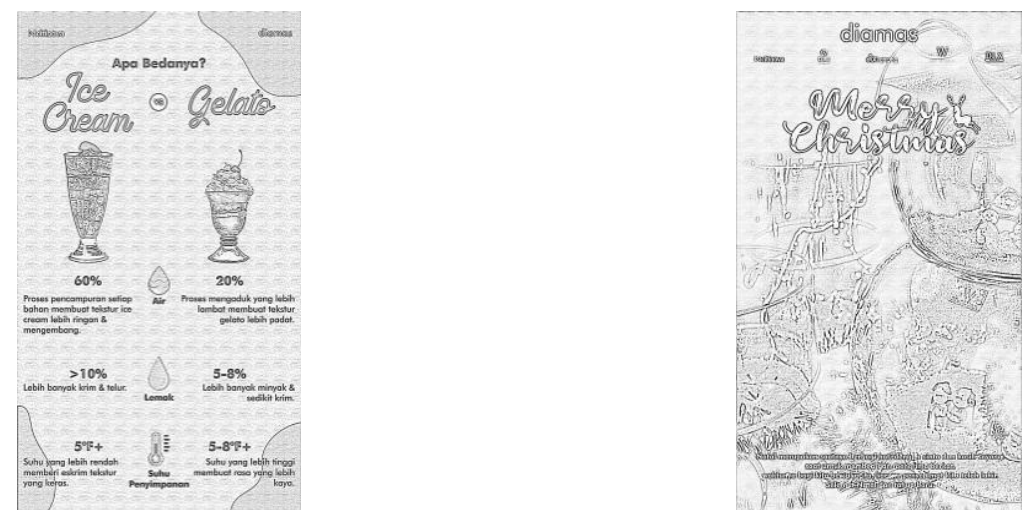

Gambar 5 dan 6. Tampilan Layout kasar dari Desain infografis Instagram Story Citinova tentang Ice Cream vs Gelato.dan Desain ucapan selamat natal untuk Instagram Story diamas.
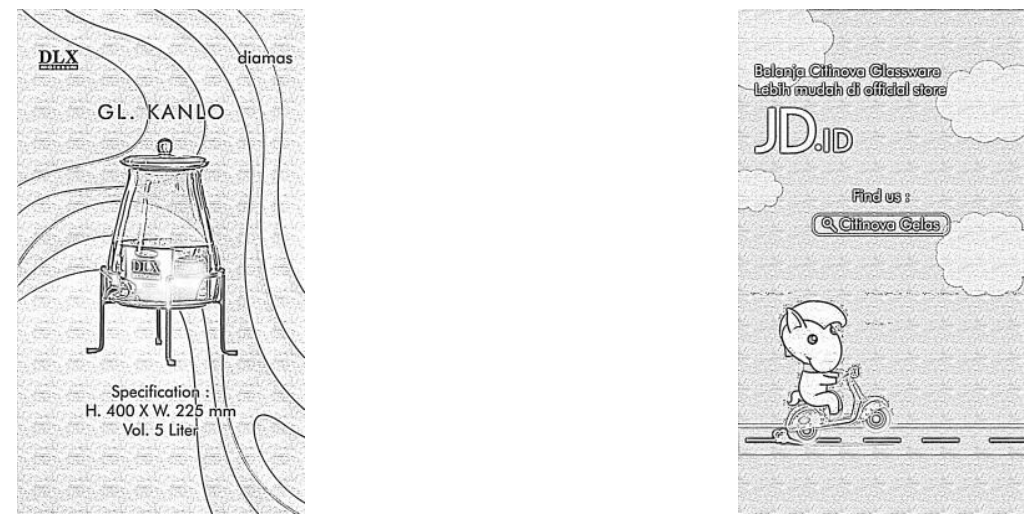

Gambar 7 dan 8. Tampilan Layout kasar dari Desain Instagram Story produk DLX Glass Diamas dan Desain Instagram Story Citinova untuk JD.ID.
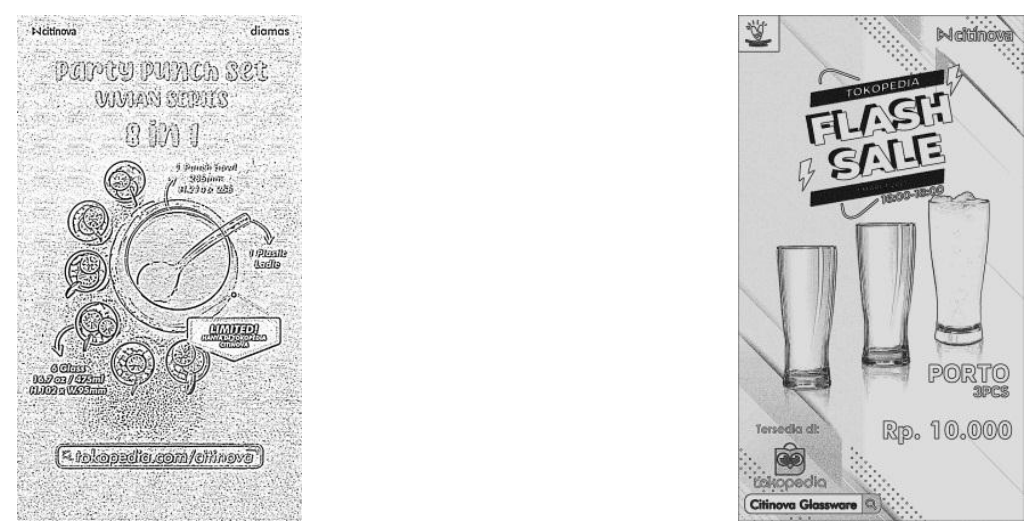

Gambar 9 dan 10. Tampilan Layout kasar dari Desain promosi Party Punch Set Instagram Story Citinova dan Desain Flash Sale Instagram Story Citinova.

\subsection{Layout Komprehensif}

Pada tahap komprehensif ini proses desain yang telah digambar dengan sketsa kasar lalu di desain kembali dan diwarnai melalu komputer. Pada tahap ini desain belum sepenuhnya selesai, dikarenakan masih harus memasuki proses revisi. Berikut adalah tampilan dari layout komprehensif : 


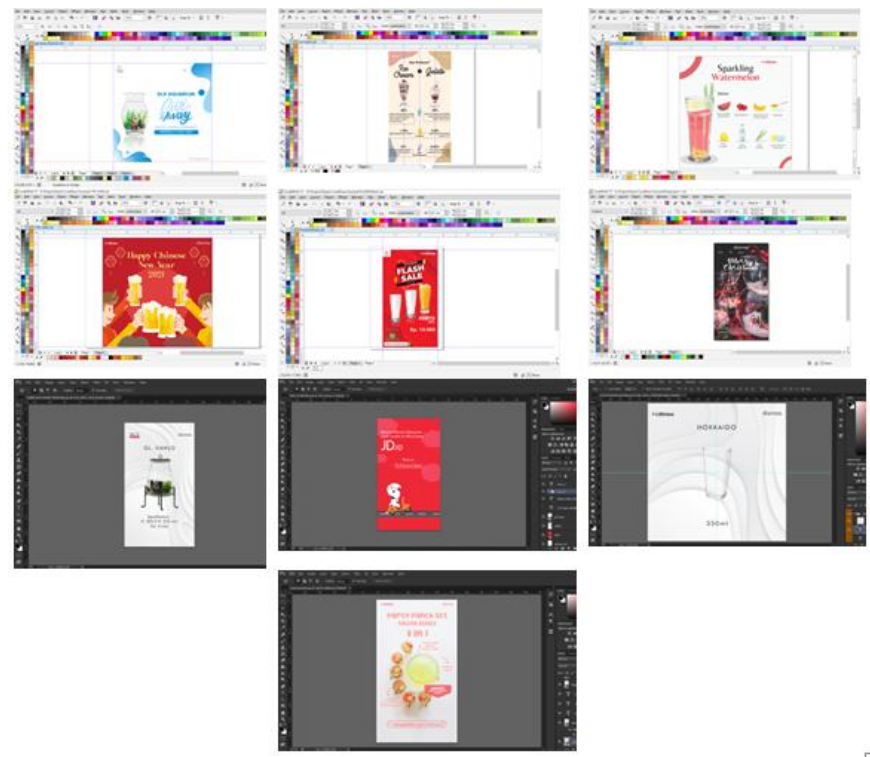

Gambar 11. Layout Komprehensif Social Media PT. Diamas Star

\subsection{Final Artwork}

Final Artworkadalah hasil akhir setelah melewati tahapan Layout kasar danLayout komprehensif yang telah diselesaikan. Pada tahap iniFinal artworkbiasa disebut sebagai file akhir/gambar dari desain yangsiap diposting di sosial media.
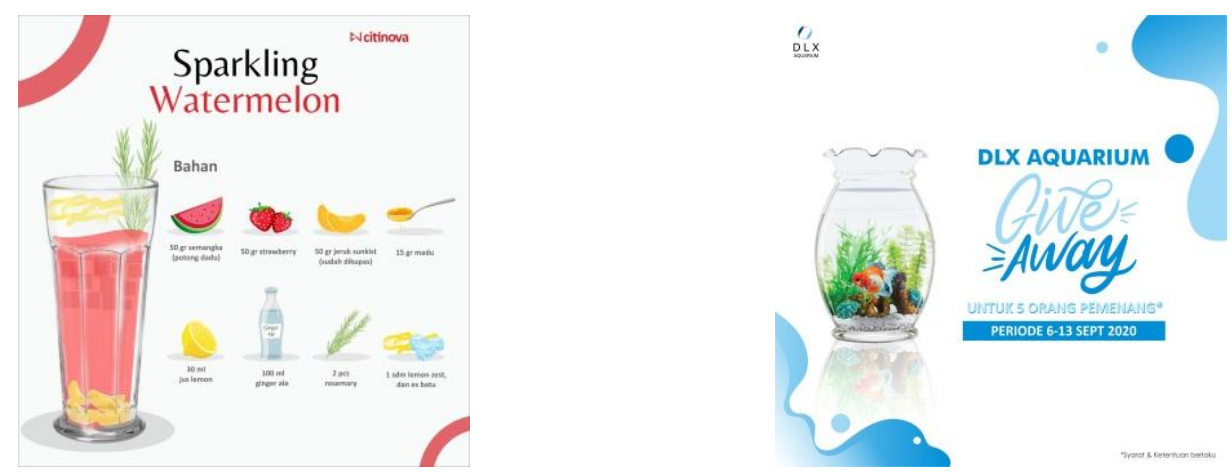

Gambar 21 dan 22. Final Artwork dari desain Give Away Feed Instagram DLX Aquarium dan Desain infografis menu Sparkling Watermelon Instagram Feed Citinova.
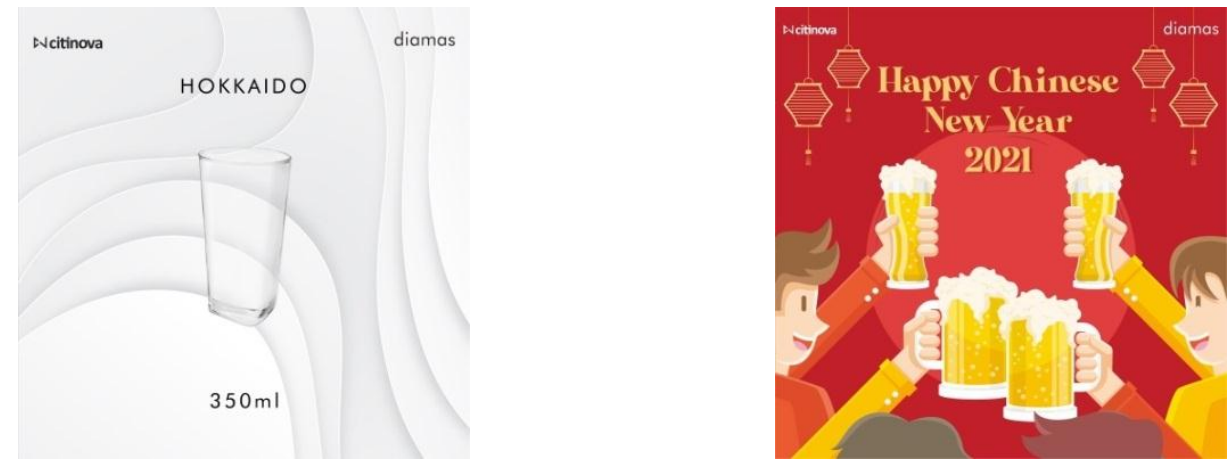

Gambar 23 dan 24.Final Artwork dari Desain produk Feed Instagram Citinova dan Desain Feed Instagram Ucapan Selamat Hari Raya Imlek 2021. 
Print ISSN: 2723-1992
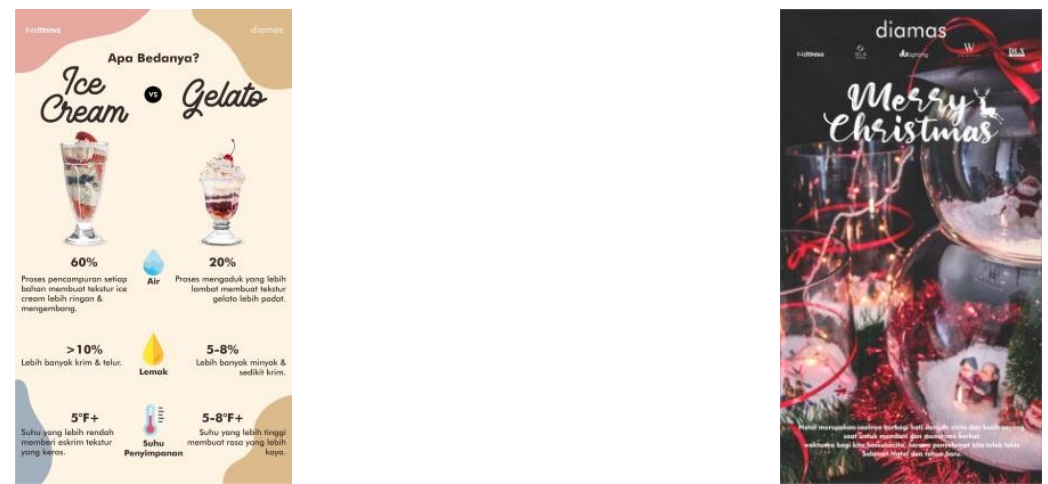

Gambar 25 dan 26. Final Artwork dari Desain infografis Instagram Story Citinova tentang Ice Cream vs Gelato dan Desain Ucapan Selamat Natal untuk Instagram Story Diamas.
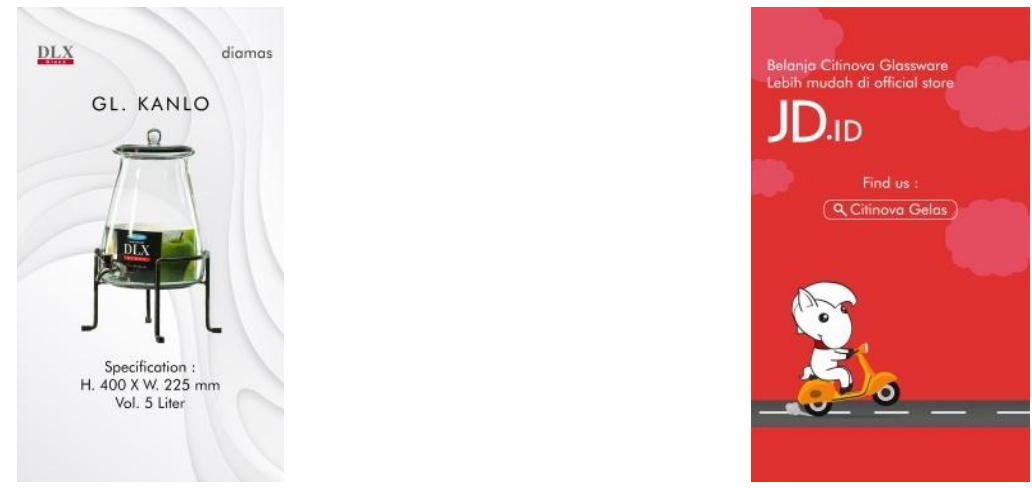

Gambar 27 dan 28. Final Artwork dari Desain Instagram Story produk DLX Glass Diamas dan Desain Instagram Story Citinova untuk JD.ID.
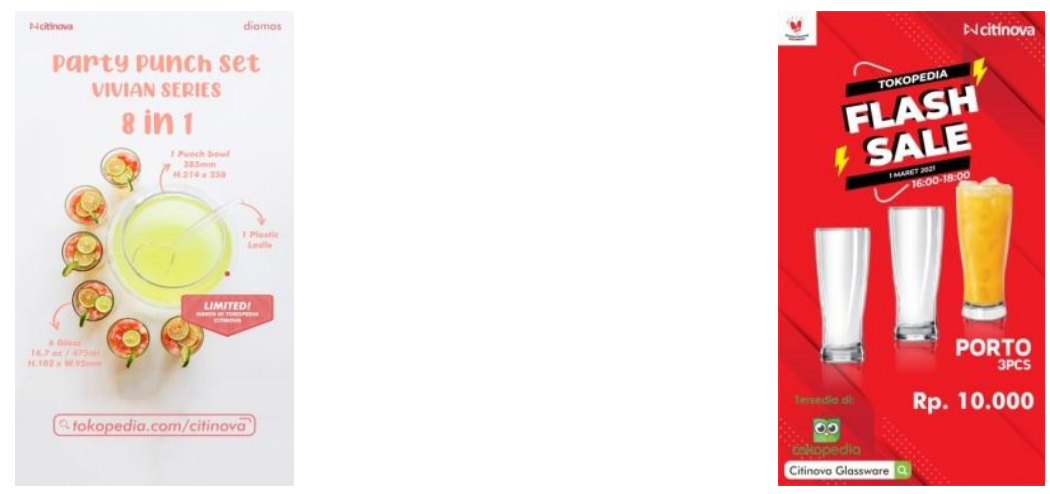

Gambar 29 dan 30.Final Artwork dari Desain promosi Party Punch Set Instagram Story Citinova dan Desain Flash Sale Instagram Story Citinova. 


\section{KESIMPULAN}

Kebutuhan desain komunikasi visual dalamdunia digital khususnya Social Mediasangatlah berperan penting dalam menyampaikan sebuah informasi dan promosi terutama dalam memperkenalkan produk-produk yang dihasilkan oleh perusahaan. Dipilihnya aplikasi Instagram sebagai media sosial yang efektif untuk kegiatan promosidengan memanfaatkan fitur postingan feed dan story ini dapat menjangkau calob konsumen dari semua kalangan serta meningkatkan penjualan dan citra PT. Diamas Star dimata konsumen, baik calon konsumen baru ataupun konsumen lama untuk menjaga kepercayaan terhadap kualitas produk.

\section{SARAN}

Mengenai saran yang dapat penulis sampaikan kepada PT. Diamas Star adalah semoga didepartemen social media khususnya desain grafis mempunyai ide-ide yang lebih fresh dan menarik sehingga bisa menjaga minat konsumen dan menarik lebih banyak lagi calon konsumen baru untuk mengetahui produk-produk yang dihasilkan dari PT. Diamas Star.

\section{DAFTAR PUSTAKA}

[1] PermanaAndrian. 2019. Pemasaran Melalui Media Sosial : Solusi Pemasaran Digital Bisnis Anda. https://seoanaksholeh.com/marketing/pemasaran-melalui-media-sosial. (Diakses tanggal 15 Maret 2020)

[2] Jatmiko. 2012. Komunikasi Pemasaran Sebagai Strategi Memperluas Pasar. Jakarta: Universitas Esa Unggul. Jurnal Komunikologi Vol. 9, No. 2, Th. 2012: Hal. 89-98. ISN: 1907-8870.

[3] Saputra, Arieza Herdy. 2011. Perancangan Media Komunikasi Visual sebagai Media Promosi Jurusan Multimedia Sekolah Menengah Kejuruan Nasional Malang. Diploma Thesis. Malang : Universitas Negeri Malang.

[4] Putra, GD Lingga Ananta Kusuma. 2011. Perancangan Media Komunikasi Visual Sebagai Sarana Promosi SD Saraswati 2 Denpasar, Tesis, Program Pasca Sarjana Seni Rupa dan Desain, Denpasar : Institut Seni Indonesia Denpasar.

[5]Amirudin, Achmad Syaiful, Daniar Wikan Setyanto, Dzuha Hening Yanuarsari. 2015. Perancangan Media Komunikasi Visual sebagai Sarana Promosi Perumahan Villa Esperanza di Semarang, Skripsi, Fakultas Ilmu Komputer. Semarang : Universitas Dian Nuswantoro.

[6] Cahyono. 2016. Pegaruh Media Sosial Terhadap Perubahan Sosial Masyarakat di Indonesia. Tulungagung : Universitas Tulungagung. Jurnal PUBLICIANA. Vol. 9, No. 1, Th. 2016: Hal. 140-157. ISN: 1979-0295.

[7] Atik, Hanifa, 2019, Unsur Desain Pada Merchandise "Tempa" di Yogyakarta. Design Elements On "Tempa" Merchandise in Yogyakarta". Yogyakarta : Universitas Negeri Yogyakarta. Jurnal SERUPA. Vol. 8, No. 4, Th. 2019: Hal. 411-422.

[8] Semuel Hatane, Setiawan Kelvin Yohanes. 2018. Promosi Melalui Sosial Media, Brand Awareness, Purchase Intentio Pada Produk Sepatu Olahraga. Surabaya : Universitas Kristen Petra. Jurnal Manajemen Pemasaran. Vol. 12, No. 1, Th. 2018: Hal. 47-52. ISN: 1907-235X.

41 
[9] I M Dedy Setiawan, N P Sukanteri, I M Suryana, dan P K Suparyana. 2019 Pengaruh Promosi Berbasis Sosial Media Terhadap Penjualan Produksi Kelompok Wanita Tani (KWT) Ayu Tangkas di Desa Megati. Bali : Universitas Pendidikan Ganesha. Jurnal Ilmu Sosial dan Humaniora. Vol. 8, No. 2, Th. 2019: Hal. 227-234. ISN: 2549-6222.

[10] Ade Raisha Nurgayatri dan Ama Suyanto. 2016. Pengaruh Promosi Online Pada Media Sosial Terhadap Keputusan Pembelian Konsumen Brand Elmeira. Bandung : Telkom University. Skripsi, Fakultas Ekonomi dan Bisnis. Bandung.

[11] Ratna Dumilah, Ading Sunarto, Ahyani Ahyani, Dede Solihin, dan Hira Maulida. 2020. Pelatihan Pemanfaatan Media Sosial Untuk Promosi Usaha Atau Bisnis Bagi Siswa. Tangerang Selatan : Universitas Pamulang. Jurnal Dedikasi PKM UNPAM. Vol. 1, No. 1, Th. 2020: Hal. 26-33. ISN: 2716-3652.

[12] Deru R Indika dan Cindy Jovita. 2017. Media Sosial Instagram Sebagai Sarana Promosi Untuk Meningkatkan Minat Beli Konsumen. Bandung : Universitas Padjadjaran. Jurnal Bisnis Terapan Politeknik Ubaya. Vol. 1, No. 1, Th. 2017: Hal. 25-31. ISN: 2580-4928. 